\title{
Sezary Cells to Leukocytes Ratio Measurement
}

National Cancer Institute

\section{Source}

National Cancer Institute. Sezary Cells to Leukocytes Ratio Measurement. NCI

Thesaurus. Code C158231.

The determination of the ratio of Sezary cells compared to total leukocytes present in a sample. The measurement may be expressed as a ratio or percentage. 